At-Turats

Jurnal Pemikiran Pendidikan Islam

\title{
THE IMPLEMENTATION OF STUDENT WRITING SKILLS OF INDONESIAN SUBJECT COURSE IN ISLAMIC EDUCATION STUDY PROGRAM
}

\author{
By: Farninda Aditya \\ Email: nindaaditya@gmail.com \\ State Institute of Islamic Studies (IAIN) Pontianak, Kalbar
}

\begin{abstract}
A B S T R A C T
This article describes the implementation of student writing skills of the Islamic religious education Program at Bahasa Indonesia language IN IAIN Pontianak. The study used case studies aimed at: 1) describing the methods of implementing students' habituation, 2) Elements of Islamic religious education in the students ' habituation writing. Data collection is done with interviews, observations, and documentation, while data analysis uses interactive data analysis Miles \& Hubberman. The results of this study indicate that; 1) method of writing habituation for students is to write a personal experience story in the diary, write about the history of life in the type of autobiography, and convey the idea of Islamic education in the form of inspirational essay writing, 2) elements of Islamic education that is habituation activities writing found in Islamic theme elections, namely the experience the religious, the famous teacher, and the Islamic education. The study recommended that Indonesian lecturers in particular and other subjects in general, continue to motivate and familiarize students in writing because it has great benefits for itself in the future.
\end{abstract}

Keywords: Writing, Bahasa Indonesia, Islamic education

\section{INTRODUCTION}

Based on his generation, Islamic religious Education student (PAI) Faculty Of Tarbiyah Teaching (FTIK) Institute of Islamic Studies (IAIN) Pontianak today that dominates is generation $\mathrm{Y}$ (millennial) and generation Z. This generation is a generation that has the ability to access information more easily. Especially related to communication technology. Bahasa Indonesia is a compulsory public lecture (MKWU) at the Islamic Religious Education Study Program (PAI) Faculty of Tarbiyah and the Science (FTIK) Institute of Islamic
Affairs (IAIN) Pontianak. Credit Unit Semester (SKS) are given for 2 hours meeting or 2 SKS. Courses in the language of Indonesia as a course of personality development to be a means of delivering information, PaseraPan Science either from various sources or as a language of profession to convey and improveThe knowledge to improve the personality of the character ${ }^{1}$.

Unfortunately, Indonesian language is considered a boring subject, because in previous education Bahasa Indonesia teaching

Stated in the Decree of National Education Minister of INDONESIA. No. 232/U/2000 on the guidelines for the preparation of higher education curriculum and core curriculum for the students ' learning outcomes. 
materials have been obtained by students. Students also claimed to be surprised to know that Bahasa Indonesia became a course in college, subjects that had been learned in EDUCATION at MI, MTs, and MA or equivalent ${ }^{2}$.

The Department of Islamic Studies (PAI) is one of the majors in the Faculty of Tarbiyah and the Study (FTIK) Institute of Islamic Religious Affairs (IAIN) Pontianak, which has selected thousands of scholars of Islamic studies. Based on the vision and mission of the PAI department, the pledge is to make the Islamic religious education means noble, professional, and competent internationally.

The vision and mission of the Islamic Religious Education Program the faculty of Tarbiyah and the teaching sciences is the Center of excellence in Islamic religious teachers, leading, open in research on the study of Science and science in 2020. Some missions of the course are conducting education, research, and devotionin the field of Islamic education and organizing education that can support the competency of qualified graduates in accordance with national standards. Realizing the vision

\footnotetext{
${ }^{2}$ This opinion is compiled from pretes activities of Indonesian language use based on PUEBI. Students are required to write their experience while obtaining Bahasa Indonesia learning materials
}

and mission OF PAI ${ }^{3}$ study Program need efforts to achieve the intended hope. From the ranking of the vision and mission it is clear that the human resource cooperation in the study program must cooperate with each other, including the lecturer, who gave the skills to the students to improvetheir competent. It is increasingly urgent when it is contacted with the intention oftheStudy of Islamic Educational studies, forming educators in the Islamic religious education thathas aprofessional competence tothe educationand competence of the steady field of Islamic religion and has a spiritof high and Islamicmend ${ }^{4}$.

Under the Higher Education Act that students are entitled to an educational service in accordance with their talents, interests, potentials, and abilities ${ }^{5}$. Based on the Act, the lecturer as a member of Sivitas Akademika has the duty to convey the knowledge that belongs to students and technological skills and knowledge that it has to students, so that the implementation of student learning is actively develop the talents, interests, potential and abilities he possesses. Thus, the implementation of Indonesian language learning as a course is no longer monotonous only the submission of theory, but students are directed to develop

\footnotetext{
${ }^{3}$ Information related to the study Program can be accessed http://ftik.iainptk.ac.id/pendidikan-agamaislam/

${ }^{4}$ Other descriptions can be found at http://ftik.iainptk.ac.id/pendidikan-agama-islam/ ${ }^{5}$ Article 13, Law number 12 year 2012 on higher education, section 13
} 
their potential through learning, prioritizing reasoning and morality, and courageous responsibly.

Writing is a must-have skill for students. This skill is a language competency in addition to listening, speaking, and listening skills that can be obtained from the Bahasa Indonesia course. Writing and Reading are two activities that students cannot get to be. These two activities always take part in a variety of lecture activities. Discussion, paper writing,observation cloth and other tasks. Writing skills are required by students to complete college assignments, complete the final task, even to increase the potential it has. Writing skills are also indispensable in modern life, with all information access that is no longer daily space and time, the skill of delivery of this information is indispensable as supporting the competency of graduates.

Writing skills are characteristic of learned people, it is conveyed by Tarigan ${ }^{6}$ . The statement has the meaning that the student must have a learned feature by having thewriting skills. Moreover , student identity as a member of Sivitas Akademika is positioned as a human being who has his own awareness in developing his own potential in higher education to become intellectuals, scientists,

6 Tarigan, Hendry Guntur. 2008. Writing: As a language skill. Bandung: space Publisher, $\mathrm{p} 4$ practitioners, and/or professionals ${ }^{7}$.

It is not undeniable, many illnesses encountered while being students who were forced to write. Put simply, write assignments and papers. Sometimes grouped papers are done by certain people, others name Temanjalan or already capital money print. Although not all students are like that but this remains a problem. Another problem is the copy and paste of another person's work, plagiarism. Change slightly, and so on. Do not want to work heavily to read and analyze, which is finally comfortable with the habit. Thinking high levels are influenced by their literary abilities. High level ability as submitted by Tuti Alawiyah ${ }^{8}$ student who joined in the club's academic Clubs Writing Institute of Islamic Religion State (Iain) Pontianak admitted that completing the task of capital copy-paste paper is "big sin". That's because it's been conscious about appreciating the copyrighted work of others.

Being a student who is accustomed to writing gives effect to the word, language, and ideas. If the ability to convey words in this form of writing is easy, then there is no possibility of plagiarism. Not only that, the ability to use the Indonesian language as a form of Bahasa Indonesia's love, understand the difference, be nationalism, improve pedagogic and competent to be trained with writing activities.

Lecturer of psychologist IAIN

\footnotetext{
${ }^{7}$ View Article 13, Law RI., number 12 year 2012 about Education High

${ }^{8}$ Author of Kubu Raya People's book, year 2018
} 
Pontianak, Agus Handini, M. Psi., psychologist explained with detailed writing benefits associated with psychology.

... In psychology study, writing is a cathartic medium. The Media is cathartic in the sense of reducing the tension experienced by the psychic, by the soul, and by the heart. Those tensions can be a burning happiness. Emotions consist essentially of two parts, namely positive emotions and negative emotions. So if that positive emotions arise excessively, such as a burninghappiness, the wailing sense of love can be reflected through writing activities. If it is a positive emotion, then it is a negative emotion like a very sore sadness, a sense of disappointment that is very heartless, or a sense of discomfort because of the negative emotions experienced by a person. ...

In the same explanation of the Faculty of Psychology lecturer Tarbiyah and the teaching knowledge is also said that in writing it is necessary to think that we write to restore the concept of Lillah, so that the writing becomes a prayer. Writing experiences is a form of writing that Agus Handini is able to apply. Writing everyday experiences, things that have been seen and witnessed by the senses will be a good habit. Writing is an effective medium in the process of catharsis or reconstitute the tension experienced by the mind and experienced by the heart. Congratulations writing, congratulations on pouring each letter in the sentence so that it becomes the content of the value ICity in the science that is beneficial.

Due to the importance of writing as skills and writing, providing benefits to students shows that these skills require habituation. Writing habits are applied through Bahasa Indonesia course, as a subject that is very closely related with language competence. Related to the mission and vision and objectives of the study Program, the good writing skills applied have an element of Ketarbiyahan and teaching science so that these skills become the competency supporting graduates for students to realize the purpose of the study Program of Islamic religion. Abdul Hamid ${ }^{9}$ explain that the purpose of the Institute of Bahasa Indonesia is the students who are able and skilled to pour ideas orally or written, both scientific and non-ilmah that are easily understood by the Society ${ }^{10}$.

This article is about implementing the implementation of academic writing skills in Bahasa Indonesia for students of Islamic Education study Program AT IAIN Pontianak for; 1) Describe the method of implementing the Habituation students Write, 2) elements of Islamic religious education in the habituation of students writing. This research is using a case study method that is the implementation of writing skills conducted by the authors as a lecturer IN Indonesian language AT PAI Ftik Iain Pontianak. Data Collectionismade with observations , interviews, and documentation, while data analysis using the DAta interactive mileage analysis \&

\footnotetext{
${ }^{9}$ In Muhammad Rohmadi and Aninditya Sri Nugraha, learn Bahasa Indonesia... hlm7
} 
Hubberman is data reduction, data serving, and conclusion and verification. Miles \& Huberman in sugiyono (2008:237), mentions that research using this way should observe the activity continuously, until the data is saturated, with a certain period of process carried out in the beginning from September to November 2019.

The observation is to see the writing activities performed by the students. The authors also observe the process of writing practice. Students are asked to write about me in approximately 15 minutes. This writing practice gives the results that there are students who write a number of 200 words. However, more students are only writing a half-page A5 size paper or about 50 words. This shows that students are still struggling to convey ideas in the form of writing. The interview stage was conducted to student in PAI first semester I to get information regarding writingexperience. The interview related to the student writing, namely The diary, has a written work, has a personal blog as a writing media, and is the champion of the writing competition. The interview showed that more students did not have a diary, there were only 2 people having a blog, and two people who won the contest writing at the timeOF thelast educator (SMA/MA).

The students have received written materials and guidance in the form of theme Briefing, the use of Bahasa Indonesia and punctuation, correction of writing and giving reinforcement related to the work he made. The result of the writing became a document to be analyzed for the development of the writing skills applied to this PAI student. From the process of the documents are being collected, analyzed and obtained the conclusion of the implementation. After BU

\section{THEORY STUDY}

\section{Variety of writings}

There are two kinds of essays known, namely fiction and non fiction. Fiction is more identical to writings derived from imaginary, not derived from actual events, or not based on facts. Non fiction is contrasted with fiction, which is based on actual events. Based on facts. Not Mengadangada. Some of the Writings of Non fiction must be accountable for the truth, And are strengthened by the source. The types of writings that are included in the variety of fiction are, poetry, prose, drama, fairy Tales, folklore, and so on. Non fiction articles are divided into two, namely in the form of scientific/academic and informative.

The following chart relates to the classification of writings by variety taken from the Literacy module book ${ }^{11}$.

\footnotetext{
${ }^{11}$ Bambang Trimansyah. 2019. Read Write Literacy module. Center for language and conversation development: Jakarta
} 
Figure 1: variety of posts

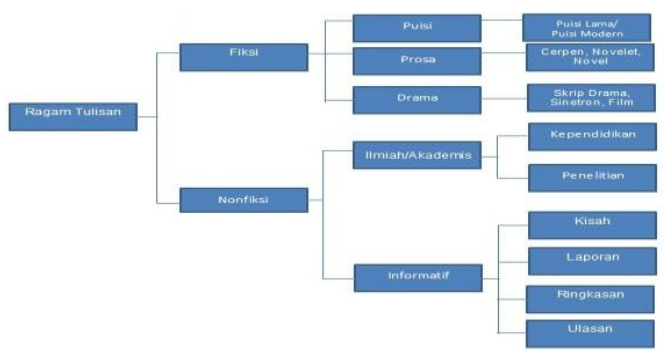

The closest thing to students in this type of scientific writing are theses, articles, essays, journals, and papers. Informative posts such as reports, reviews, and featured. In other terms, the essay is divided into three types, namely scientific essay, Semi-Scientific, and Non-scientific essay. The scientific essay is similar to Non fiction in the ILMIah/academic category. Scientific arrangement is a writing that comes from observation, observation or research process. The scientific essay relates to the author's expert field. Semi scientific arrangement, if associated with a variety of Non fiction writings entered on informative writing. This article can be found in newspapers in the opinion, Editorial, reviewer, anecdote, Hikayat and featured columns. Not melulu only in newspapers, other media publications such as online media and books can also be found this type of writing.

Non scientific essay, similar to the variety of writings fiction. Articles that are not based on facts, writings derived from the imagination and design of the author, and more subjective. The language used in this essay is more relaxed, language that is easily accepted by readers, often comes from personal experience.

In non scientific essay there is a type of essay or paragraph that is always attached, namely exposition (explanation), description (depiction), argumentation (Opinion), and narrative (a). Of the 4 (four) types of this essay is not only found in a single essay. So in one essay can be found more. For example, in the writing short story (Cerpen), which is the nature of narrative, writings that tell stories but in the story can be found descriptive essay that used to describe the figure of the figure, as well as from the viewpoint of the figure ( Point of View), in which it conveys arguments.

Related to the variety of posts, one can create posts of different types. There is more to master the writing of fiction there is also Non fiction, there are also the usual to master both. The creative process of writing can be sharpened. A person or in this case the student should not first decide that he can only write poetry, short stories, articles only, or Pantun only. Because, creative process is needed to hone this ability.

\section{Starting a writing habit}

Kebiasaan menulis sebenarnya sudah dilakukan. Faktanya adalah menulis status di media sosial. Hanya saja menulis status di media sosial dibatasi jumlah karakter setiap satu kali menulis status. Selain itu, menulis di media sosial memiliki pengaruh emosi, 
baik emosi positif maupun negatif. Media sosial dapat dipantau oleh orang banyak, dan penilaian dari netizen pasti beragam.

Pada penjelasan tentang manfaat menulis disebutkan tentang menulis pengalaman sebagai sarana terapi katarsis. Menghilangkan rasa ketegangan dari energi emosi positif maupun negatif. Tulisan Pribadi adalah satu di antara media yang dapat digunakan dan diterapkan membiasakan menulis. Tarigan menjelaskan bahwa buku harian termasuk bentuk tulisan pribadi. Bentuk tulisan pribadi lainya sebagaimana gambar berikut:

\section{Figure 2: The four types of personal writings (Tarigan: 2008)}

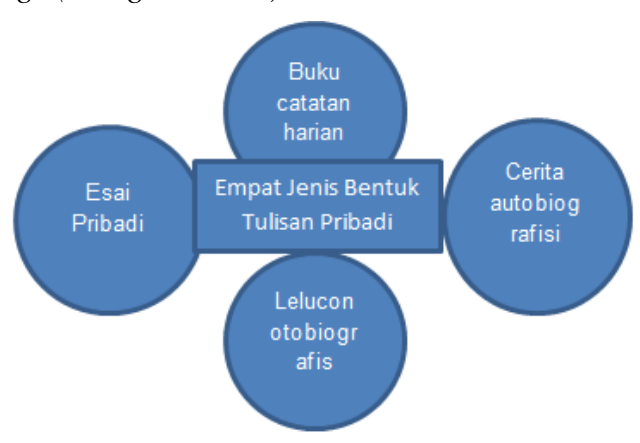

vocabulary.

Writer in West Kalimantan, Pay Jarot Sujarwo claimed to have a diary in 2011 already 71 The diary that he had 12 Yusriadi and Tarigan also suggest this way to be done as a teaching in writing. Yusriadi made this way as a mandatory task in Bahasa Indonesia class at IAIN Pontianak.

In his book develop a writing culture: the entry of a lecturer, the diary is a ${ }^{13}$ powerful way to make students do not plagiarism. The diary makes the students do their job seriously. Initially he assigned students to read the EyD book, create a newspaper clipping, apparently not as expected. Students don't really read, newspaper clippings are made while in class, let alone papers. Students obviously copy-paste.

In his story (2012:51) Yusriadi also reveals that during his experience guiding students write him, finding that a skilled student writes, active students, likes to read,

\section{a. Diary}

This diary is a means of honesty that makes writers easier to convey something. Honesty based on this experience usually does not require thinking that my writing should be good. It is because the diary is an expression of heart and thought that will be read on its own and its privacy. In regard to the habit, students can practice and add are those who write a diary.

\section{b. Autobiography}

Write your own profile. Write about life's experiences. Writing autobiography requires a soundtrack of time, events, places, even direct quotations. Writing an

12

http://nindafarnindaaditya.blogspot.com/2012/01/wo w-untuk-pay-jarot-sujarwo.html

13 Joseph. 2012. Developing a writing culture: The record of a lecturer. Pontianak: STAIN Pontianak Press 
autobiography requires a description essay to give you an idea of a self profile.

\section{c. Personal essays}

More personal essays on discussing the experience expressed instead of telling the experience. So writing a personal essay is a problem or issue that we foster. The issue comes from personal experience. Discussions regarding this experience require the red thread the reason the story was delivered. There is an inspiration to the inscription.

The essay is conveyed by storytelling or story. This writing is relaxing. Referring to $\mathrm{KBBI}$, essays are a prose essay that discusses a mone in a shortcut then from the personal point of the author. Essays include a type of non fiction essay, although conveyed with storytelling style. So essay writing does match the facts.

\section{d. Writing articles}

The article belongs to the category of semi-scientific essay. In this regard requires an expert opinion as an amplifier of the idea conveyed. This method has been tested to the students, the results of the form systematics of the article, consisting of an introduction to the issue of issues, both reinforcing theories on the issue, then attributed to the evidence and the interpretation of authors related to the evidence chosen, the three ideas of reinforcement related issues raised. Fourth conclusion.

The argument is closely related to the article. Article is a type of semi-scientific writing. Articles with outline, content, and cover. The articles need resources to reinforce their writings. Writing articles benefits students when making a thesis, because it is accustomed to conclude the reading results.

\section{IMPLEMENTATION OF WRITING SKILLS}

1. Diary

Diary aims to make students accustomed to writing. Students who are accustomed to writing will be easier to convey or give proper diction to his writings. Here are some steps that can be applied to write the student Diary of PAI study Program:

a. Choose a book to use for writing a diary. The book chosen is an easy-to-carry book and not a book that mixes with other notes;

b. Give identity to the book. The identity is listed in name, class, Semester and No. Hp;

c. Specialize writing. Special meaning of writing written in the diary is an interesting and inspiring, especially religious-related experience;

d. Occasionally reading writings are made as reflections.

The Bahasa Indonesia academic 
meeting begins with a lecture contract which is to write a diary. Students are required to have a diary and write about experience in the diary for a number of 500 words per week. Total 500 words if in a diary is approximately 3 pages. Each diary meeting is reported to the lecturer to obtain the Paraf. The Paraf was made to mark $\mathrm{P}-1$ for the first meeting, P-2 for the second meeting, and the iron. This Paraf mark to control the writing that the student made.

This assignment as a student exercise writes without thinking theory in writing. Students are allowed to write stories that they think are worthy of writing. In addition, the diary becomes a control of the use of Indonesian language in accordance with the rules. Initially, students showed inseriousness writing because it wrote 500 words according to students too much. Found posts that are just one page, or one half page. But after the 8th meeting, the writing in the diary shows an increase of the quantity of writing. Students are even no longer writing per week 500 words, but there are already writing in one week one theme. In the diary belonging to Nisha Putriani, PAI class E he wrote in one day 175 words, at the time of the diary report of the third week of the meeting Nisha wrote a number of 980 words.

Besides Nisha, Muhammad Izma
Wahyuda showed similar things. Yuda every day writes 112 words in a single report, it can produce a text of an average number of 784 words. The diary of Nur Amalia is unique, writing daily with an erratic number of words. At least, the diary is written in 11 words. There are 7 writing themes that Nur Amalia made, he classifies his writings by day, and date, for example Monday, October 28, 2019. At the 10th meeting Nur Amalia reported in his diary for a total of 704 words. Jamaliah student PAI class A, reported his writings per week, in the first week of 616 words.

\section{Writing autobiography}

Writing autobiography gives a good effect on students to remember the events of the past. Show the good luck he earned. Because being a student in the Islamic Religious Education study Program is certainly not easy, many rivals are faced. Not to mention a blatal financial. Many of the peers are not getting college opportunities. The steps can be used to write autobiography as follows:

a. Personal identity

Identity consists of name, place of birth date, address, blood type, height, occupation, this item some are often found in the ID card. The identity we can emulate by following the sequence, but write it with essay.

b. Family

Writing about a family can start from: 
Parents, parents, parents ' work, number of corners, or about siblings.

c. Education

Experience about education from ELEMENTARY to college. About your friends, teachers, assignments, unforgettable experiences in school, can be a self-improvement about yourself.

Writing about yourself is the easiest thing. In this story there are descriptions of self-discussing. At the meeting two students were asked to tell the story of his life or autobiography. This assignment was intended for students to gain learning about his life story. Students take the wisdom of the various challenges he faced until now a student. Biographical writing begins with introducing yourself first of all. The Following is written by Rocy Wahyudi, class E STUDENT PAI.

"Introducing my name is Rocy Wahyudi, I am from Sungai Ayak, Sekadau regency. I am now a student of IAIN Pontianak. I was born from 2 siblings. I have a younger sister who is now sitting in class IX junior high School. My father was named Ahmad youngest and my mother was named Saleha. Many interesting things that I experienced...., but I do not want to dissolve in sadness..."

\section{This Rocy writing provides} learning about its life. Before becoming a student he suffered grief and he was able to solve the problem. Experience of Islamic education obtained by students. An example of this writing is written by Cintya Bela class B student PAI:

"I began to learn the Koran from an early age that was when I was attending the PAUD. At that moment my parents taught me to read Hijaiyah letters well and correctly. By the time I sat on the first class school, my parents went to the Nurul Islami Al-Qur'an Education park located not far from my place.

When the first day I learned to pay in the TPA, I was introduced to a Ustazah there which is commonly called as Bunda Zahra. Not only mother Zahra, but there are also other Ustazah who are familiar to be called by the name of Mother Devi, mother Umi and mother Mai. I was also introduced to students who learned to pay in TPA. The activity of the Koran at TPA Nurul Islami starts from after Asar until nine o'clock in the evening.

Every afternoon my abahi always drove me to the TPA. Not only the science of reading the Koran I gained, but also the science of reading the Yellow Book and also there is learning of fiqh science. I am a new student at this TPA, I introduced first learning to read the Qur'an starting from Iqra as a beginner before reading the holy Book of the Qur'an. Mother Zahra every day always guide me so that I can read the Koran and Tajwid law."

In addition to Autobiography, students also write about their teacher's biography through their respective perspectives. Here's the writing Rocy Wahyudi:

Alhamdulillah Now I am already an adult and now a student OF IAIN Pontianak. Now he is my best friend and I have already admired him as my own brother. Thanks to his being able from the time I was a child, until now I can become a person who can always be in his religion Allah SWT. Thanks to him I can be a better person of his fellow friends, polite 
and respectful to older people, and always be grateful for the pleasure of God.

I would like to reply to his services that have made me like this time, and wherever he is if there is a safari Ramadan event, Tablig Akbar, and the mawlid of Prophet Muhammad SAW He always invites me to join the event so that I can be more able to add insight about religion. He taught me how to respect others. My time in Grade 12 SMA used to teach me the readings, prayers and requirements of being a priest."

\section{Personal essays}

Implementation of writing this personal essay, students first be blessed the opportunity to gain an interesting experience. In a personal essay writing session, students are directed to join the activity and then write down the inspiration gained. The activity in the implementation of this personal essay writing is the Literacy Festival and the Month party language which is part of Bahasa Indonesia lecture. The inscription from Anggrialdi Idafi about the month of language it follows:

". .. Commemorating the month of the language, we of the Department of Islamic Religion Faculty of Tarbiyah and the teaching field to make the activities of the language month, the activities are not a race, but rather make mading that content about the linguistic. I see poetry and short stories for friends, some of which add a diversity of languages in Indonesia. Like Dayak language, Malay language, and Javanese language, this means that the diversity of languages in Indonesia in each region has a diversity of languages, but Bahasa Indonesia is what makes every diversity of languages in Indonesia to be the language of unity that we should keep. Do not because different languages make us split together, we are proud to have a diversity of languages. On the day of the boy's oath I ordered, "Let us make Bahasa Indonesia as a language of unity, and also do not forget the language of our region, Jangan because different languages we t..." the

\section{Writing articles}

Cara yang digunakan dalam menulis artikel untuk mahasiswa dalam buku pada penerapan keterampilan menulis artikel mata kuliah Bahasa Indonesia ini ialah memberikan soal. Soal terdiri dari 5 sampai 6, soal dibuat untuk mengarahkan mahasiswa menulis artikel. Strategi ini disebut Strategi Tanya Jawab. Pertanyaan yang diberikan kepada mahasiswa sebagai pola menulis artikel dengan Kalimat Tanya sebagai berikut:

1. What do you think about Islamic religious education in the present?

2. What do you think is the definition of Islamic religious education?

3. Give a verse or evidence relating to your opinion?

4. Give expert opinion about Definisi Islamic religious education!

5. Mention the evidence related to Islamic religious education, and give your opinion (Tafsir) related to the evidence.

6. As a student, how to apply the science of Islamic education in daily life.

7. Copy all answers from the number 1 to 5 .

\footnotetext{
"TheUrgency of Islamic religious education for millennials generation youth

By: Rocy, student PAI FTIK IAIN Pontianak
} 
In this day, Islamic education is very important to young men because of the trials and challenges they face are far greater and much heavier than in the previous decades. Millennials are more susceptible to falling into deviant deeds due to several factors.

One such factor is the youths of this age have been neglected with a rectangular object that makes them unwrapped in empty time they fill with unfaith. The object is called a smartphone. If it is reviewed from the positive side, there are many things that we can take from the smartphone, one of them as a means of communication and search for various science with a help device called Internet.

But the youths of this age, the majority of them use smartphones to immortally. If in ancient times the people were quite silent in the house to avoid the diverse of Fitanh and the martial. However this is not the case in the millennial period. Now we can easily access negative content in the form of gossip as well as in the form of pornography and pornographic action wherever and whenever including our own home.

Religious education is very important for young people in this age so that they know the etiquette of using smartphones so that they can reap the benefits that many of them and they can escape from sin caused by misuse of technology in the distorted direction.

Islamic religious education is an academic means to study the sciences contained in the breadth of Islamic treasures so that for those who want to learn about Islamic religious education correctly, he will gain knowledge of various important encyclopedias in the Islamic world that will be his life guidelines.

Drs. Burlian Somad underscores the notion of Islamic religious education is "an education called Islamic education, if the education aims to form individuals into self- patterned, the highest degree according to God and the content of education to realize that purpose is the teaching of God" (quoted from "some issues in Islamic education".)

Allah speaks in the Qur'an which means "say whether it is the same among the people who are knowledgeable with the unknowledgeable. Indeed, a God who can receive lessons ". From this verse, the author concluded that Allah has differentiated between people who are knowledgeable with the unsciences so that on this basis, it is mandatory for a muslin to study and to learn. One way is by tasting Isl am Religious education.

As an Islamic campus student, authors apply the science of Islamic education in daily life such as applying the values of Tauhid, keep the obligatory prayers five time, read the Qur'an, devoted to both parents, and the no less important is to avoid all kinds of shirk, both ancient and modern, such as reading and the prediction of stars or zodiac and various other kinds of mistakes.

In order to apply all of the tilapia-the value of the Islamic, it is certainly mandatory for every Muslim to study their religion so that they do not leave the teachings that are listed in the Qur'an and As-Sunnah or Al-hadist.

For millennials, it is not impossible to achieve and be found because for those who may not be a student of Islamic campus or no education in pesantren, they can still follow the Islamic studies found in mosques around their environment so that they also get the sciences of Islam and it will not leave them behind with the students of Islamic campuses in achieving religious sciences. "

\section{Conclusion}

The existence of the resulting work, the student who claimed to feel unbelievers can write, especially wrote the book. Students admitted that they felt proud of the work produced. Students realize that writing is very important to life, and know that anyone can write. They understand the fun 
and the effort to produce writing.

This research recommends that Indonesian lecturers in particular and other courses in general, continue to motivate and familiarize students with writing because they have great benefits for themselves in the future. Students need guidance to apply habituation writing.

\section{REFFERENCE}

A.S Laksana. 2006. Creative Writing. Depok: Media Kita

Bambang Trimansyah.2019. Modul Literasi Baca Tulis. Pusat Pengembangan Bahasa dan Perbukuan: Jakarta

Muhammad Rohmadi dan Aninditya. 2011.

Belajar Bahasa Indonesia: Upaya Terampil Berbicara dan Menulis Karya Ilmiah. Surakarta: Cakrawala Media

Tarigan, Hendry Guntur. 2008. Menulis:Sebagai Suatu Keterampilan Berbahasa. Bandung: Penerbit Angkasa

Yusriadi. 2015. Ajarkanlah Anakmu Menulis. Pontanak: STAIN Pontianak Press

Yusriadi. 2012. Mengembangkan Budaya Tulis: Catatan Lepas Seorang Dosen. Pontianak:STAIN Pontianak Press

Sugiyono. 2008. Metode Penelitian

Kuantitatif Kualitatif dan $R \& D$. Bandung : Alfabeta

\section{Regulations:}

Surat Keputusan Menteri Pendidikan Nasional RI. No. 232/U/2000 tentang Pedoman Penyusunan Kurikulum Pendidikan Tinggi dan Kurikulum Inti Pendidikan Tinggi serta Penilaian hasil Belajar Mahasiswa.

Undang-Undang Nomor 12 Tahun 2012 tentang Pendidikan Tinggi

Farninda Aditya.

http://nindafarnindaaditya.blogspot .com/2012/01/wow-untuk-payjarot-sujarwo.html, akses

November 2019
Humas. 2019. ftik.iainptk.ac.id/pendidikanagama-islam/.akses November 2019 